\title{
Composition and nutritive value of whole maize plants fed fresh to sheep. II. Prediction of the in vivo organic matter digestibility
}

\author{
P Dardenne 1, J Andrieu 2, Y Barrière 3, R Biston 1, \\ C Demarquilly 2, N Femenias 4, M Lila 3 , \\ P Maupetit 5, F Rivière 6, T Ronsin 4
}

\author{
1 Station de Haute Belgique, rue de Serpont, 100, 6800 Libramont, Belgium; \\ 2 INRA, Station de Recherches sur la Nutrition des Herbivores, 63122 Theix; \\ 3 INRA, Station d'Amélioration des Plantes Fourragères, 86600 Lusignan; \\ ${ }^{4}$ Limagrain, Station Expérimentale de Mons, 63203 Riom; \\ 5 ITCF, Institut Technique des Céréales et des Fourrages, 91720 Boigneville; \\ 6 ITCF, Institut Technique des Céreales et des Fourrages, 44370 Varades, France
}

(Received15 May 1992; accepted 21 September 1992)

\begin{abstract}
Summary - In vivo trials on sheep carried out in France in 1987 and 1988 run by INRA, AGPM, ITCF and breeders led to prediction models for in vivo organic matter digestibility coefficient of whole plant maize used for silage. The new equations account for 60 to $70 \%$ of the variability observed in the in vivo digestibility values. It is difficult to improve these results when we add variation sources: those from the location and plant diversity, and those from experiments on animals and laboratory methods. Near infrared spectroscopy (NIRS) can replace laboratory measures to estimate each of the chemical constituents and in vivo digestibility. These results are used to research the best laboratory prediction reference methods. Direct determination by NIRS of in vivo organic matter digestibility is feasible but at present the data basis does not involve all variation sources and might lead to prediction errors. To improve NIRS performance, we have to standardize the reference method at an international level and set up a wider data base.
\end{abstract}

feeding value / maize / digestibility / in vivo / Near Infrared Spectroscopy (NIRS)

Résumé - Composition et valeur alimentaire de la plante entière verte de maïs pour les ovins. II. Prédiction de coefficient de digestibilité in vivo de la matière organique. Des essais de mesures de bilan sur moutons réalisés en France en 1987 et 1988, conduits par IIINRA, I'AGPM, I'ITCF et des sélectionneurs, ont permis d'établir des modèles de prévision du coefficient de digestibilité in vivo de la matière organique du maïs plante entière destiné à l'ensilage. Les 234 bilans sur animaux proviennent de 16 variétés cultivées sur 7 centres de recherche capables de réaliser les mesures in vivo. Les paramètres disponibles sont l'âge de la plante à la récolte, la somme de température, le pourcentage de grains et d'épis, la matière sèche, la composition chimique (cendres, protéines, cellulose, NDF, $A D F, A D L$, amidon et glucides solubles) et 3 digestibilités enzymatiques 
(tableau I). Une étude de ces variables par ACP permet de dégager 4 directions dominantes (tableau II et fig 1). Des prédictions croisées centre par centre du coefficient de digestibilité in vivo (OMD) ont conduit à devoir écarter les données de 2 centres. Ceux-ci présentent des écarts inexplicables dans les valeurs OMD in vivo. Sur 199 bilans restants, toutes les combinaisons de critères ont été évaluées pour arriver au modèle le plus précis:

$O M D=38,3+0,390 L G S=0,1021 C P+0,0923 A G E-0,0152 D M-0,1844 A D L ;$ $S E C=1,58 ; R=0,83$

Dans la pratique, des modèles simplifiés sont proposés: $O M D=14,6+0,1034 C P+0,6322$ LGS pour les utilisateurs de la méthode "Ensitec" (Ronsin et Femenias, 1990); $O M D=24,5+0,1001 \mathrm{CP}$ $+0,5671$ THE pour les utilisateurs de la méthode Aufrère (Aufrère et Michalet-Doreau, 1983). Les nouvelles équations expliquent de 60 a $70 \%$ de la variabilité observée sur les valeurs de digestibilité in vivo. II est difficile de faire mieux lorsque l'on accumule les sources de variations: celles liées à la diversité des lieux et des plantes et celles liées à l'expérimentation sur animaux et aux méthodes de laboratoires. La spectrométrie dans l'infrarouge proche (SPIR) peut se substituer aux mesures de laboratoire afin d'estimer chacun des constituants chimiques et la digestibilité enzymatique (tableau VII). Ces résultats servent alors à calculer la digestibilité in vivo considérée comme la méthode de référence. L'estimation directe par SPIR de la digestibilité in vivo de la matière organique est possible et présente une précision excellente, mais actuellement la base de données n'intègre pas toutes les sources de variation du maïs destiné à l'ensilage et son utilisation pourrait conduire à des erreurs de prédiction difficilement décelables, vu la difficulté et le coût des déterminations in vivo. Un effort doit être entrepris au niveau international pour standardiser la méthode de référence et permettre la constitution d'une banque d'échantillons plus large. La standardisation des spectromètres dans le proche infrarouge (Dardenne et al, 1990) devrait permettre la mise en commun des bases spectrales et le développement d'un modèle unique de prévision du coefficient de digestibilité in vivo.

valeur alimentaire / maïs / digestibilité / in vivo / spectrométrie dans le proche infrarouge (SPIR)

\section{INTRODUCTION}

Ruminant production depends among other factors on the quality of the feed ration which has to provide the energy necessary to meet both animal needs and the requirements of the microbes in their rumen. A good knowledge of the maize value that constitutes an important proportion of the energy provided by the ration and of the intake is necessary for those involved in rationing.

The prediction of the energetic value depends mainly on organic matter digestibility $(O M D)$. The latter varies according to varieties, and to phytotechnical, climatic and preservation conditions. In this paper, we will deal with the methods of predicting in vivo OMD.
Near-infrared spectroscopy (NIRS) is a physical analytical method that requires calibrations. The studies carried out on forages (Norris et al, 1976; Shenk et al, 1981; Biston et al, 1985) indicate that this method enables prediction of the values obtained by any other method used for predicting digestibility, either chemical, microbiological, enzymatic or the in vivo reference method itself.

The results presented here are based on the data provided by the "Club Digestibilité" group, which includes INRA, AGPM, ITCF (France), CRA in Gembloux (Belgium), and several breeding companies. The samples were used to show the relationship between in vivo $O M D$ and morphological, chemical and enzymatic criteria and to develop prediction models. These different parameters and in vivo OMD were used to calibrate NIRS. 


\section{MATERIAL}

The trials carried out by the "Club Digestibilité" deal with 16 varieties of maize, including one hybrid, $\mathrm{BM} 3$, which were grown in 7 areas in 1987 and 1988. The general trial conditions, the measurements in plants and animals, sample preparation and laboratory analyses have been described by Andrieu et al (1993).

Table I shows the mean, range and coefficient of variation of the available predictors and the in vivo $O M D$. The second part of table I shows the same parameters for the 8 brown midrib samples (BM3); the contents are fairly similar to those of other varieties except for lignin $(A D L)$ - the $A D L$ value is $13 \mathrm{~g} / \mathrm{kg}$ against $24 \mathrm{~g} / \mathrm{kg}$ for the other 226 samples. These extremely weak lignin contents account for the very high values of enzymatic solubilities whatever method we use, and for in vivo $O M D$ as well $(78.5 \%)$. Removing the BM3 samples from the global file reduces the in vivo $O M D$ variability and the $S D$ decreases from $2.81(N=234)$ to $2.56(N=226)$.

\section{PRINCIPAL COMPONENT ANALYSIS}

A principal component analysis (STATITCF package) was performed on the 234 samples and 16 parameters (1 to 16 in table I), the $O M D$ being considered a supplementary variable. This analysis is calculated on the centred standardized variables; ie on the correlation matrix. Figure 1 displays the correlation circle for the first 2 axes which accounts for $73.2 \%$ of the total variance.

Representing the variables on the first 2 axes leads to a better understanding of the correlation matrix (table II). Four variable groups can be considered independent:

- water-soluble carbohydrates (WSC) and starch (STA) contents are highly correlated to morphological criteria ( $A G E, S T 6, G R A$, EAR);

- cell-wall contents (CF, ADF, NDF, $A D L$ ) are inversely correlated to enzymatic solubilities. A link exists between fibre content and the growing stage;

- protein content $(C P)$ makes a group on its own and is not correlated to the other parameters. The $C P$ variability is not accounted for on the first 2 axes. $C P$ requires an independent axis: the third with a correlation of -0.86 ;

- ash content $(A S H)$ has the same behaviour as protein content and is independent of the other parameters and is mainly represented on axis $4(R=-0.72)$.

The in vivo OMD coefficient is located on the direction linking the cell-wall content and enzymatic solubilities. We therefore note that these criteria are the most effective in predicting $O M D$. $O M D$ variability is justified at $45 \%$ with the first 2 axes, at $47 \%$ with the first 4 axes and only at $62 \%$ with 10 dimensions. We already have to conclude that it will be impossible to com-

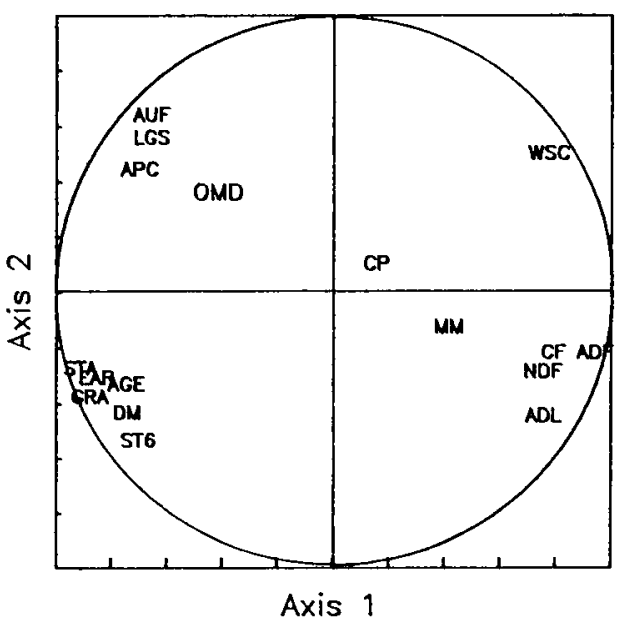

Fig 1. First 2 axes of PCA with the 16 predictors of OMD: $73.2 \%$ of the total variance. 
pletely explain the $O M D$ variability of these 234 samples with the available parameters. Other unmeasured parameters (Andrieu et al, 1993) and/or the weak reproducibility of the animal trials are held responsible for the remaining $O M D$ variability.

Computing the generalized distance between each sample and the centre of gravity in the space of the 10 principal compo- nents shows that the BM3 samples are not the most extreme points. They generally reveal a large distance but other samples are even more remote from the centre. So it seems logical to retain these samples in the estimation of predictive models. These samples add a variability which enables us to increase the correlations with available predictors.

Table I. Chemical and nutritive value of maize. A: means, ranges and variation coefficients observed in the 234 samples; B: means, ranges and variation coefficients observed in the 8 BM3 samples with low lignin and high digestibility.

Abb Mean Range $\begin{gathered}\text { Variation } \\ \text { coefficient (\%) }\end{gathered}$

A. $N=234$

Age at cropping (d/flowering)

Temperature sum ${ }^{a}$

49

$20-82$

27

Morphological composition ( $/ \mathrm{kg}$ DM)

Grain

ST6

558

$270-913$

23

Ear

GRA

370

510

75-590

270-680

31

$E A R$

$D M$

$\mathrm{ASH}$

291

48

$C P$

74

CF 208

NDF $\quad 473$

ADF $\quad 229$

$A D L$

24

STA

236

WSC

119

183-531

33-80

$50-99$

157-280

389-575

174-302

11-37

29-404

36-226

19

Water-soluble carbohydrates

AUF $\quad 71.0$

71.0

61.2-83.1

LGS

79.6

70.3-88.7

$A P C$

$70.6-90.3$

21

17

12

11

7

11

21
34

34

Enzymatic solubility (\%)
Aufrere's method b
Limagrain method c
Lila's method
In vivo digestibility (\%)
Organic matter

$O M D$

71.9

66.5-80.6

4

a Computed from the flowering time to the harvest on a basis of $6^{\circ} \mathrm{C}$; Abb: abbreviation. ${ }^{\mathrm{b}}$ Aufrère et MichaletDoreau, 1983. c Ronsin et Femenias, 1990. 


\section{CROSS-PREDICTIONS}

In order to study the influence of each trial for a given year and a given site, each of them is removed from the global matrix one by one. The predictive model is calculated excluding one trial and then applied to the data of this trial to estimate the $O M D$. Tables III and IV display the results of this analysis.

Table III displays the models for the 12 trials each with 1 trial excluded. The table shows the number of samples, the variables introduced in the models, the multiple correlation coefficients and the residual SDs. The choice of the predictors differs according to the excluded data set. The variables common to all the models are $C P, S T 6, D M$ associated with an enzymatic solubility (11 $\times$ AUF and $1 \times$ LGS $)$. The complementary variables are grain percentage (GRA) and time from flowering (AGE) or starch (STA) or cell wall contents (CF, NDF, ADF or $A D L$ ).

Table I. Continued

$A b b$

Mean

Range

Variation

coefficient (\%)

B. $N=8$

\section{Age at cropping \\ (d/flowering)}

Temperature sum ${ }^{2}$

Morphological composition (g/kg DM)

Grain

Ear

Chemical composition $(\mathrm{g} / \mathrm{kg}$ )

Dry matter

Total ash

Crude protein

Crude fibre

NDF (Van Soest)

$A D F$ (Van Soest)

$A D L$ (Van Soest)

Starch (Ewers)

Water-soluble carbohydrates

Enzymatic solubility (\%)

Aufrere's method ${ }^{b}$

Limagrain method $\mathrm{c}$

Lila's method

In vivo digestibility (\%)

Organic matter
AGE

ST6

GRA

$E A R$

$D M$

$M M$

$C P$

$C F$

$N D F$

$A D F$

$A D L$

STA

WSC

$A \cup F$

LGS

$A P C$

$O M D$
40

$21-55$

26

492

270-706

27

348

$170-490$

374-604

27

15

$207-355 \quad 18$

$35-52 \quad 13$

73-86

168-228

406-501

179-239

10-17

35-301

$121-170$

$77.6-83.1$

85.5-88.7

86.4-90.3

88.6

78.5

$75.1-80.6$

4

a Computed from the flowering time to the harvest on a basis of $6{ }^{\circ} \mathrm{C}$; Abb: abbreviation. ${ }^{b}$ Aufrere et MichaletDoreau, 1983. ${ }^{\circ}$ Ronsin et Femenias, 1990. 
Table II. Correlation matrix between the predictors and $O M D(N=234)$.

\begin{tabular}{|c|c|c|c|c|c|c|}
\hline & 2 ST6 & $3 G R A$ & $4 E A R$ & $5 D M$ & $6 A S H$ & $7 C P$ \\
\hline \multirow[t]{2}{*}{$\begin{array}{l}1 \text { AGE } \\
2 \text { ST6 } \\
3 \text { GRA } \\
4 \text { EAR } \\
5 \text { DM } \\
6 \text { ASH }\end{array}$} & $0.707^{\star \star \star *}$ & $\begin{array}{l}0.781^{* * *} \\
0.791^{* * *}\end{array}$ & $\begin{array}{l}0.705^{\star * \star} \\
0.729^{* * *} \\
0.936^{* * *}\end{array}$ & $\begin{array}{l}0.609^{* * *} \\
0.763^{* * *} \\
0.760^{* * *} \\
0.692^{* * *}\end{array}$ & $\begin{array}{l}-0.102 \\
-0.160^{*} \\
-0.350^{* * *} \\
-0.298^{* * *} \\
-0.414^{* * *}\end{array}$ & $\begin{array}{l}-0.211^{* *} \\
-0.065 \\
-0.148^{*} \\
-0.039 \\
-0.186^{* *} \\
0.149^{*}\end{array}$ \\
\hline & $8 \mathrm{CF}$ & $9 N D F$ & $10 \mathrm{ADF}$ & $11 A D L$ & $12 S T A$ & 13 WSC \\
\hline $\begin{array}{l}1 A G E \\
2 S T 6 \\
3 \text { GRA } \\
4 E A R \\
5 D M \\
6 A S H \\
7 \mathrm{CP} \\
8 \mathrm{CF} \\
9 \mathrm{NDF} \\
10 \mathrm{ADF} \\
11 \mathrm{ADL} \\
12 S T A\end{array}$ & $\begin{array}{c}-0.626^{\star \star \star} \\
-0.536^{\star \star \star} \\
-0.709^{* * *} \\
-0.730^{* * *} \\
-0.431^{\star * *} \\
0.278^{\star \star *} \\
-0.063\end{array}$ & $\begin{array}{l}-0.486^{* \star *} \\
-0.458^{\star \star *} \\
-0.620^{* * *} \\
-0.581^{* * *} \\
-0.466^{* * *} \\
0.414^{* * *} \\
0.035 \\
0.811^{* * *}\end{array}$ & 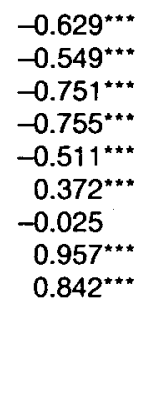 & $\begin{array}{l}-0.477^{* * *} \\
-0.320^{* * *} \\
-0.509^{* * *} \\
-0.523^{* * *} \\
-0.381^{* * *} \\
0.280^{* * *} \\
0.073 \\
0.699^{* * *} \\
0.633^{* * *} \\
0.779^{* * *}\end{array}$ & $\begin{array}{l}0.762^{* * *} \\
0.788 \\
0.932^{* * *} \\
0.898^{* * *} \\
0.733^{* * *} \\
-0.374^{\star * *} \\
-0.087 \\
-0.816^{* * *} \\
-0.704^{* * *} \\
-0.847^{\star \star *} \\
-0.563^{* * *}\end{array}$ & $\begin{array}{c}-0.750^{* * *} \\
-0.735^{* * *} \\
-0.861^{* * *} \\
-0.835^{* * *} \\
-0.739^{* * *} \\
0.216^{* *} \\
0.090 \\
0.544^{* * *} \\
0.455^{* * *} \\
0.603^{* * *} \\
0.418^{* * *} \\
-0.873^{* * *}\end{array}$ \\
\hline & 14 AUF & 15 LGS & $16 A P C$ & $17 O M D$ & & \\
\hline $\begin{array}{l}1 \text { AGE } \\
2 \text { ST6 } \\
3 \text { GRA } \\
4 \text { EAR } \\
5 \text { DM } \\
6 \text { ASH } \\
7 \mathrm{CP} \\
8 \mathrm{CF} \\
9 \mathrm{NDF} \\
10 \mathrm{ADF} \\
11 \mathrm{ADL} \\
12 \mathrm{STA} \\
13 \mathrm{WSC} \\
14 \mathrm{AUF} \\
15 \mathrm{LGS} \\
16 \mathrm{APC}\end{array}$ & 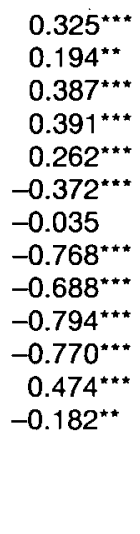 & 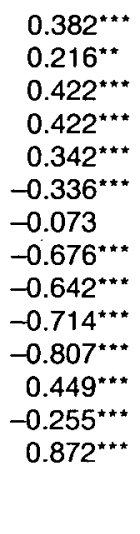 & 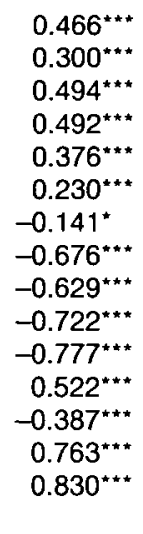 & 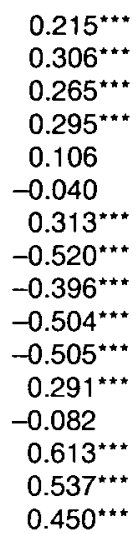 & & \\
\hline
\end{tabular}

F-test on the correlation coefficients at the level : ${ }^{*} 5 \% ;{ }^{* *} 1 \% ;{ }^{* * *} 0.1 \%$. 
Table III. Selected predictors and precision of $O M D$ models when removing 1 trial.

\begin{tabular}{|c|c|c|c|c|c|c|c|c|c|}
\hline $\begin{array}{l}\text { Removed } \\
\text { trial }\end{array}$ & $N$ & & & Predic & ors & & & $\mathrm{Rc}$ & RSD \\
\hline $1 \mathrm{TH} 87$ & 204 & GRA & STA & $A U F$ & $D M$ & $C P$ & ST6 & 0.80 & 1.68 \\
\hline 2 RE 87 & 219 & $A U F$ & ST6 & $C P$ & STA & $D M$ & GRA & 0.79 & 1.76 \\
\hline 3 LU 87 & 211 & $A U F$ & ST6 & $C P$ & $D M$ & $A D F$ & & 0.75 & 1.75 \\
\hline 4 LE 87 & 218 & AUF & ST6 & $C P$ & $D M$ & $N D F$ & & 0.79 & 1.73 \\
\hline $5 \mathrm{DI} \quad 87$ & 222 & AUF & ST6 & $C P$ & $A D F$ & $D M$ & $A D L$ & 0.82 & 1.61 \\
\hline 6 LA 87 & 218 & $A U F$ & ST6 & $C P$ & STA & $D M$ & GRA & 0.81 & 1.71 \\
\hline 7 TH 88 & 209 & $A U F$ & ST6 & $C P$ & $D M$ & STA & GRA & 0.79 & 1.73 \\
\hline 8 RE 88 & 222 & $A U F$ & ST6 & $C P$ & $D M$ & $A D F$ & $A D L$ & 0.78 & 1.70 \\
\hline $9 \mathrm{LU} 88$ & 213 & $A \cup F$ & ST6 & $C P$ & STA & $D M$ & GRA & 0.78 & 1.70 \\
\hline 10 LE 88 & 211 & $D M$ & $C P$ & LGS & $A D L$ & ST6 & $A G E$ & 0.82 & 1.63 \\
\hline 11 LA 88 & 207 & $A U F$ & ST6 & $D M$ & $C F$ & $C P$ & & 0.77 & 1.78 \\
\hline 12 TO 88 & 220 & $A U F$ & ST6 & $C P$ & STA & $D M$ & GRA & 0.78 & 1.77 \\
\hline
\end{tabular}

$N$ : number of samples; $R c$ :correlation coefficient; $R S D$ : residual standard deviation; 1 TH $87:$ Theix 1987; 2 RE 87: Rennes, 1987; 3 LU 87 : Lusignan, 1987; 4 LE 87: Lepin, 1987; 5 DI 87: Dijon, 1987; 6 LA 87: Lajallière, $1987 ; 7$ TH 88: Theix, 1988; 8 RE 88: Rennes, 1988; 9 LU 88: Lusignan, 1988; 10 LE 88: Lepin, 1988; 11 LA 88: Lajalliere, 1988; 12 TO 88: Toulouse, 1988.

Table IV. Trial by trial prediction of $O M D$ using the model set up without this trial.

\begin{tabular}{llllllr}
\hline $\begin{array}{l}\text { Predicted } \\
\text { trial }\end{array}$ & N & Sdy & Hbar & Rp & Sep & Bias \\
\hline & & & & & & \\
1 TH 87 & 30 & 2.94 & 1.4 & 0.66 & 2.24 & -0.45 \\
2 RE 87 & 15 & 0.98 & 0.7 & 0.40 & 1.23 & 0.28 \\
3 LU 87 & 23 & 2.55 & 1.3 & 0.70 & 1.97 & 0.43 \\
4 LE 87 & 16 & 1.96 & 1.0 & 0.24 & 2.79 & -1.35 \\
5 D 87 & 12 & 1.80 & 0.6 & 0.83 & 3.50 & 3.20 \\
6 LA 87 & 16 & 1.09 & 4.4 & 0.00 & 2.29 & 0.99 \\
7 TH 88 & 25 & 2.46 & 1.0 & 0.77 & 1.85 & -0.88 \\
8 RE 88 & 12 & 0.89 & 0.6 & 0.24 & 2.50 & 2.19 \\
9 LU 88 & 21 & 3.25 & 1.6 & 0.85 & 1.75 & -0.20 \\
10 LE 88 & 23 & 0.96 & 1.6 & 0.10 & 4.88 & -4.41 \\
11 LA 88 & 27 & 1.05 & 1.9 & 0.35 & 2.23 & -1.89 \\
12 TO 88 & 14 & 2.20 & 0.7 & 0.92 & 0.89 & 0.08 \\
Total & 234 & 2.82 & & & & \\
\hline
\end{tabular}

$N$ : number of samples; Sdy. OMD standard deviation generalized; Hbar: generalized mean distance of the samples in the space of the predictors used in the model; Rp. correlation coefficient of prediction; Sep: residual root mean square; Bias: difference of means; Total: pooled value. 
The multiple correlation coefficients vary from 0.75 to 0.82 . The weakest is obtained when leaving out the samples from Lusignan in 1987. The reduction in the in vivo $O M D$ variability by taking out the $\mathrm{BM} 3$ samples accounts for this lower correlation. The residual SDs vary from 1.61 to 1.78. The 2 weakest values are obtained when trials 5 and 10 are left out. The residual SE reduction, when these samples are ignored, shows that these points disturb the model by important residues. Table IV gives the statistical values when applying the previously obtained models on the data of each coresponding trial. It shows the number of samples, the SD of in vivo values, the mean distance of the predicted samples from the centre of gravity of the samples on which the models are determined and within the space of the predictors used. This distance is a generalized distance computed from the principal components analysis (PCA) scores and normalized in such a way that the mean distance of the model samples from its centre of gravity is always equal to 1 . A sample is considered as an outlier when its distance is $>3$ (Shenk and Westerhaus, 1991).

Table IV also displays the correlation coefficients, the root mean squares and the biases between the in vivo values and those predicted by the model. We notice that the highest Seps are observed for the trials number 5 and 10 , with respectively 3.50 and 4.88 corresponding to biases of 3.20 and -4.41 . Figure 2 shows the scatter diagram of the points between the reference values and the predicted values for these 2 trial sets. The introduction of these points in the predictive models will surely disturb the coefficient stability and the accuracy.

Barrière et al (1991) have shown obvious site effects. Those cannot be split into a so-called "sheep" effect and a site effect (climate, soil, etc). The morphological, chemical and enzymatic data do not allow us to conclude that these samples are different from the others. The distances of these samples in the predictor space are rather weak to suspect the reference values themselves. No explanation could be found in the experimental design or in the chemical and enzymatic determinations.

Trial number 6 shows high distances $(H=4.4)$ which come in fact from dry matter $(D M)$ of the maize given to the sheep. This $D M$ is abnormally high in comparison with starch content or with the cutting date. In spite of these high distances, the accuracy of the prediction remains acceptable. The zero correlation comes from the very weak variation in the reference values (OMD standard deviation generalized, $S d y$ $=1.06$ ).

All the residues ( $N=234$ ) provide a pooled root mean square equal to 2.50 and a correlation coefficient of 0.54 . These values are obviously less good than those observed when calibrating and show how it is difficult to define a stable model.

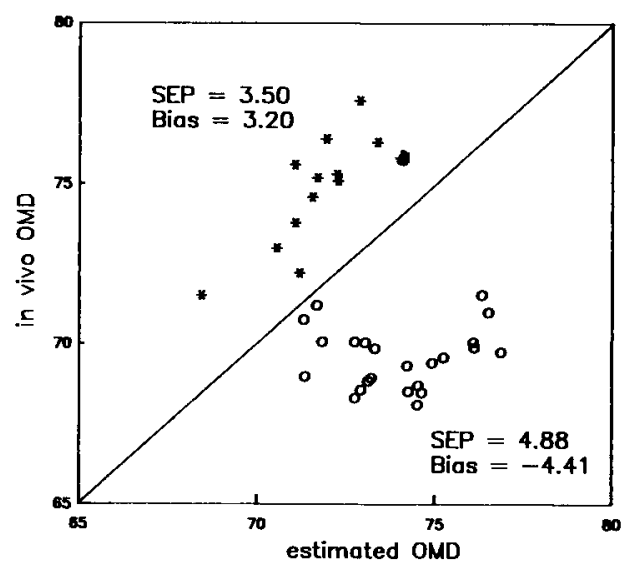

Fig 2. Scatter diagram between in vivo values and predicted values by models developed without these 2 trials (": Dijon, 1987; 0: Lepin, 1988). 
After leaving out the trials number 5 and 10 , we repeated the cross-prediction procedure among the 10 remaining trials $(N=$ 199). In this study, the residual SEs vary from 1.41 to 1.51 with a respective correlation of 0.87 and 0.82 . In prediction, the highest error reaches 2.57 for trial number 8 while the cumulated error for 199 samples is equal to 1.85 with a correlation of 0.75 . When deleting trials 5 and 10 , we obtain in prediction on independent samples an acceptable accuracy (residual root mean square, $\operatorname{Sep}=1.85$ ) for predicting $O M D$.

In order to assess the linearity of the relation between $O M D$ and the different predictors, the in vivo conditional means were calculated on the basis of LGS values. Table $V$ shows the 11 points calculated with the number of samples for each class, the mean LGS solubility and the mean of in vivo $O M D$ for the corresponding samples, the in vivo values computed by simple regression $(O M D=22.0+0.636$ LGS $)$ and the residues.

The scatter diagram (fig 3 ) shows the linearity between in vivo $O M D$ and $L G S$ enzymatic solubility. Fortunately we notice that the extreme point obtained by aver- aging the $8 \mathrm{BM} 3$ hybrid samples falls into the line with the others and that it is a very influential point but not an outlier. Besides, it is to be noticed that the regression slope and the intercept are very close to those obtained from the 199 points. Averaging in vivo values through years and sites enables us to reach a correlation of 0.96 with LGS solubility. The AUF mean values are correlated to 0.995 with the LGS values.

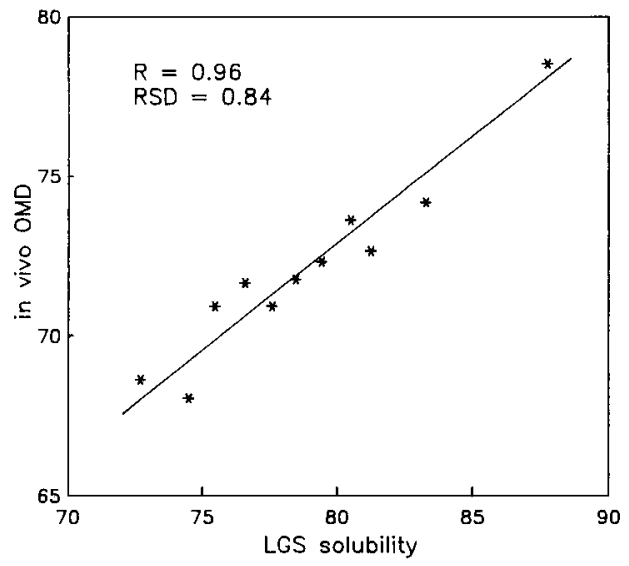

Fig 3. Relation between in vivo $O M D$ and $L G S$ solubility with the means of 11 classes based on LGS.

Table V. OMD conditional means for 11 classes of $L G S$ values.

\begin{tabular}{rrrlllr}
\hline & Class interval & N & $\begin{array}{l}\text { Mean } \\
\text { LGS }\end{array}$ & $\begin{array}{l}\text { Mean } \\
\text { in vivo OMD }\end{array}$ & $\begin{array}{l}\text { Estimated } \\
\text { OMD }\end{array}$ & Residues \\
\hline & & & & & & \\
1 & $\leq 74$ & 10 & 72.7 & 68.6 & 68.2 & 0.4 \\
2 & $74<$ to $\leq 75$ & 7 & 74.5 & 68.1 & 69.3 & -1.3 \\
3 & $75<$ to $\leq 76$ & 13 & 75.5 & 70.9 & 70.0 & 1.0 \\
4 & $76<$ to $\leq 77$ & 24 & 76.6 & 71.7 & 70.7 & 1.0 \\
5 & $77<$ to $\leq 78$ & 22 & 77.6 & 70.9 & 71.3 & -0.4 \\
6 & $78<$ to $\leq 79$ & 41 & 78.5 & 71.8 & 71.9 & -0.1 \\
7 & $79<$ to $\leq 80$ & 26 & 79.4 & 72.3 & 72.5 & -0.1 \\
8 & $80<$ to $\leq 81$ & 26 & 80.5 & 73.6 & 73.2 & 0.5 \\
9 & $81<$ to $\leq 82$ & 15 & 81.2 & 72.7 & 73.6 & -1.0 \\
10 & $82<$ to $\leq 84$ & 7 & 83.3 & 74.2 & 74.9 & -0.7 \\
11 & $>84$ & 8 & 87.7 & 78.5 & 77.8 & 0.8 \\
\hline
\end{tabular}


The bias between both methods is equal to 7.88. The conditional means are useful to check the linearity but do not represent the reality when estimating individual values.

\section{PREDICTION OF OMD}

The linear models are calculated by the least squares method. Instead of the stepby-step method, the best combination of criteria is determined by computing all the possible combinations of 2 criteria out of 16 (120 combinations), of 3 criteria out of 16 (560 combinations), of 4 criteria out of 16 (1820 combinations) and so on. The search for the best combination was performed on the 199 samples file. Table VI shows all the equations. The regression coefficients with $T$-test $<2$ were not kept. The models were estimated from 9 groups of criteria: 1) all criteria of table I (1 to 16) (table VI.1); 2) all criteria except LGS enzymatic solubility for those using Aufrère's method (table VI.2); 3) chemical criteria and enzymatic solubilities (table VI.3); 4) chemical criteria and Aufrère's solubility (AUF) (table VI.4); 5) chemical criteria without Van Soest's fractions and with LGS solubility (table VI.5); 6) chemical criteria without Van Soest's fractions and with AUF solubility (table VI.6); 7) chemical and morphological criteria (1-13) (table VI.7); 8) only chemical criteria (6-13) (table VI.8); 9) chemical criteria without Van Soest's fractions $(6,7,8,12$ and 13) (table VI.9).

From the 199 samples, the first criterion is lignin content with a correlation of 0.66 with OMD (table VI.1). However, the AUF and $L G S$ solubilities have very close correlations (0.65). This is the reason why the corresponding equations are displayed in table VI.1 and VI.2 (equations [1.1a] and [2.1a]).
The second criterion is protein content, which provides a significant contribution. The correlation coefficient goes from 0.66 to 0.74 when $C P$ is associated with LGS solubility. It is also noticed that the 3 criteria $L G S, A U F$ and $A D L$ can easily be replaced by each other. If we consider the $L G S+C P, A U F+C P$ and $A D L+C P$ equations, the correlation coefficient are respectively $0.74,0.73$ and 0.73 with similar accuracy $(1.91 ; 1.92$ and 1.92$)$.

The third criterion is the age after flowering time ( $A G E$ ). Yet its contribution is already reduced compared to that of $C P$.

The fourth criterion is the dry matter content of the given maize. However, by introducing this parameter, the AGE criteria is replaced by the temperature sum (ST6) (equation [1.4]).

The fifth variable is $A D L$ when the first criterion is an enzymatic solubility. Thus, its contribution is weak and its information is redundant. The most effective equation is equation [1.5] which reaches a correlation of 0.83 and a residual SD of 1.58 .

When the morphological criteria are not available, it is possible to use the models 3.1 to 4.5 (table VI.3 and VI.4). Among these, the third variable is $A D L$ and the fourth total ash (ASH). There is a high similarity between equations [3] and [4] and accuracies are similar for models with up to 4 terms.

It is interesting to develop models without values relative to the Van Soest fractions. The models with $L G S$ and AUF are shown in table VI.5 and VI.6. We add crude fibre $(C F)$ and ash to the pair LGS$C P$ and starch (STA) and ash to the pair $A U F-C P$. There is little difference between models 3.3 and 5.3 and crude fibre can replace $A D L$. However, the difference between models 4.3 and 6.3 is more important.

Table VI.7 and VI.8 do not take solubilities into account. The models in table VI.7 
are similar to those of tables VI.1 and VI.2 where $A D L$ replaces solubilities. The models in table VI.8 look like those in table VI.3. The ASH content as predictor is not very significant from a zootechnical point of view. This parameter is artificially entered to take account of a special site, ie Rennes in 1988. So, equation VI.3a is the next best model with 3 terms and $C F$ seems a more effective predictor than ASH.

In equation [8.3a], $A D F$ replaces $C F$ because it is very easy to obtain $A D F$ when $A D L$ is determined according to Van Soest's method.
Table VI.9 gives the models without solubilities and without Van Soest fractions. Crude fibre expresses cell walls, and starch and water soluble carbohydrates are considered as explanatory variables but with very weak contributions.

Among all these models, we will only keep those which are easy to use routinely. Model 1.5 is the most accurate $(R=$ $0.85 \mathrm{SEC}=1.58$ ), but requires $A D L$ determination. The previous model 1.4 is almost as precise without $A D L(R=0.82, S E C=$ 1.63). Model 1.4 is to be used when temperature sum and maize $D M$ are known. If these criteria are not available, the easiest

Table VI. OMD prediction based on 199 in vivo samples from different combinations of predictors.

\begin{tabular}{llllllll}
\hline Equation & 0 & 1 & 2 & 3 & 4 & 5 & $\begin{array}{c}\text { Rc } \\
\text { RSD }\end{array}$ \\
\hline
\end{tabular}

VI.1. All the criteria (1 to 16 )

\begin{tabular}{|c|c|c|c|c|c|c|c|}
\hline 1.1 & & $A D L$ & & & & & \\
\hline$\ddot{T}$ & & 12.3 & & & & & 0.66 \\
\hline$L$ & 82.1 & -0.4087 & & & & & 2.13 \\
\hline $1.1 \mathrm{a}$ & & LGS & & & & & \\
\hline$T$ & & 12.0 & & & & & 0.65 \\
\hline$K$ & 23.9 & 0.6120 & & & & & 2.15 \\
\hline 1.2 & & LGS & $C P$ & & & & \\
\hline$T$ & & 13.9 & 7.4 & & & & 0.74 \\
\hline$K$ & 14.8 & 0.6322 & 0.1034 & & & & 1.91 \\
\hline 1.3 & & LGS & $C P$ & $A G E$ & & & \\
\hline$T$ & & 12.5 & 8.7 & 5.5 & & & 0.78 \\
\hline$K$ & 16.8 & 0.5561 & 0.1162 & 0.00592 & & & 1.77 \\
\hline 1.4 & & LGS & $C P$ & ST6 & $D M$ & & \\
\hline$T$ & & 16.3 & 7.3 & 8.4 & 7.2 & & 0.82 \\
\hline$K$ & 12.4 & 0.6721 & 0.08972 & 0.01098 & -0.02088 & & 1.63 \\
\hline $1.4 \mathrm{a}$ & & LGS & $C P$ & $A G E$ & $D M$ & & \\
\hline$T$ & & 12.6 & 8.1 & 6.5 & 3.8 & & 0.79 \\
\hline$K$ & 27.1 & 0.5026 & 0.10709 & 0.08718 & -0.09740 & & 1.75 \\
\hline 1.5 & & LGS & $C P$ & $A G E$ & $D M$ & $A D L$ & \\
\hline$T$ & & 6.0 & 8.5 & 7.7 & 6.5 & 4.1 & 0.83 \\
\hline$K$ & 38.3 & 0.3900 & 0.10209 & 0.09229 & -0.01521 & -0.18439 & 1.58 \\
\hline
\end{tabular}


Table VI. Continued

\begin{tabular}{lllllllll}
\hline Equation & 0 & 1 & 2 & 3 & 4 & 5 & Rc \\
& & & & & & & & \\
\hline
\end{tabular}

VI.2. All the criteria 1 to 13 and AUF solubility

\begin{tabular}{|c|c|c|c|c|c|c|c|}
\hline $\begin{array}{l}2.1 \\
T \\
K\end{array}$ & 82.1 & $\begin{array}{l}A D L \\
12.3 \\
-0.4087\end{array}$ & & & & & $\begin{array}{l}0.66 \\
2.13\end{array}$ \\
\hline $\begin{array}{l}2.1 \mathrm{a} \\
T \\
K\end{array}$ & 32.9 & $\begin{array}{l}A U F \\
12.0 \\
0.5527\end{array}$ & & & & & $\begin{array}{l}0.65 \\
2.15\end{array}$ \\
\hline $\begin{array}{l}2.2 \\
T \\
K\end{array}$ & 75.1 & $\begin{array}{l}A D L \\
13.7 \\
-0.4127\end{array}$ & $\begin{array}{l}C P \\
6.8 \\
0.09538\end{array}$ & & & & $\begin{array}{l}0.73 \\
1.92\end{array}$ \\
\hline $\begin{array}{l}2.2 \mathrm{a} \\
T \\
K\end{array}$ & 24.4 & $\begin{array}{l}A U F \\
13.7 \\
0.5660\end{array}$ & $\begin{array}{l}C P \\
7.1 \\
0.10032\end{array}$ & & & & $\begin{array}{l}0.73 \\
1.92\end{array}$ \\
\hline $\begin{array}{l}2.3 \\
T \\
K\end{array}$ & 25.8 & $\begin{array}{l}A \cup F \\
12.0 \\
0.4952\end{array}$ & $\begin{array}{l}C P \\
8.3 \\
0.1129\end{array}$ & $\begin{array}{l}A G E \\
5.1 \\
0.05660\end{array}$ & & & $\begin{array}{l}0.77 \\
1.81\end{array}$ \\
\hline $\begin{array}{l}2.4 \\
T \\
K\end{array}$ & 74.7 & $\begin{array}{l}A D L \\
13.1 \\
-0.3957\end{array}$ & $\begin{array}{l}C P \\
9.6 \\
0.09632\end{array}$ & $\begin{array}{l}A G E \\
6.7 \\
0.08792\end{array}$ & $\begin{array}{l}D M \\
5.8 \\
-0.01476\end{array}$ & & $\begin{array}{l}0.80 \\
1.71\end{array}$ \\
\hline $\begin{array}{l}2.4 \mathrm{a} \\
T \\
K\end{array}$ & 24.0 & $\begin{array}{l}\text { AUF } \\
14.9 \\
0.5691\end{array}$ & $\begin{array}{l}C P \\
7.0 \\
0.09109\end{array}$ & $\begin{array}{l}\text { ST6 } \\
7.2 \\
0.00991\end{array}$ & $\begin{array}{l}D M \\
5.4 \\
-0.01476\end{array}$ & & $\begin{array}{l}0.80 \\
1.71\end{array}$ \\
\hline $\begin{array}{l}2.5 \\
T \\
K\end{array}$ & 45.2 & $\begin{array}{l}A D I \\
4.3 \\
-0.2021\end{array}$ & $\begin{array}{l}C P \\
7.0 \\
0.08648\end{array}$ & $\begin{array}{l}\text { ST6 } \\
6.6 \\
0.00883\end{array}$ & $\begin{array}{l}D M \\
6.0 \\
-0.01748\end{array}$ & $\begin{array}{l}A U F \\
5.9 \\
0.3593\end{array}$ & $\begin{array}{l}0.82 \\
1.64\end{array}$ \\
\hline
\end{tabular}

VI.3. Chemical criteria and solubilities (6 to 16)

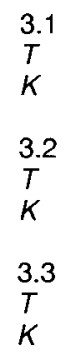

$\begin{array}{llll} & A D L & & \\ & 12.3 & & \\ 82.1 & -0.4087 & & \\ & & & \\ & \text { LGS } & C P & \\ & 13.9 & 7.4 & \\ 14.6 & 0.6322 & 0.1034 & \\ & & & \\ & \text { LGS } & C P & A D L \\ 41.6 & 4.8 & 7.5 & 4.5 \\ & 0.3603 & 0.1003 & -0.2198\end{array}$


Table VI. Continued

\begin{tabular}{|c|c|c|c|c|c|c|c|}
\hline Equation & 0 & 1 & 2 & 3 & 4 & 5 & $\begin{array}{l}R c \\
R S D\end{array}$ \\
\hline $\begin{array}{l}3.4 \\
T \\
K\end{array}$ & 34.9 & $\begin{array}{l}\text { LGS } \\
5.7 \\
0.4133\end{array}$ & $\begin{array}{l}C P \\
7.0 \\
0.09082\end{array}$ & $\begin{array}{l}A D L \\
4.9 \\
-0.2292\end{array}$ & $\begin{array}{l}A S H \\
4.4 \\
0.07236\end{array}$ & & $\begin{array}{l}0.79 \\
1.74\end{array}$ \\
\hline $\begin{array}{l}3.5 \\
T \\
K\end{array}$ & 50.0 & $\begin{array}{l}\text { LGS } \\
4.8 \\
0.3506\end{array}$ & $\begin{array}{l}C P \\
6.5 \\
0.08345\end{array}$ & $\begin{array}{l}C F \\
3.4 \\
-0.02561\end{array}$ & $\begin{array}{l}A S H \\
4.7 \\
0.07520\end{array}$ & $\begin{array}{l}A D L \\
3.6 \\
-0.1754\end{array}$ & $\begin{array}{l}0.80 \\
1.69\end{array}$ \\
\hline
\end{tabular}

VI.4. Chemical criteria and AUF solubility ( 6 and 13 and 14)

\begin{tabular}{|c|c|c|c|c|c|c|c|}
\hline $\begin{array}{l}4.1 \\
T \\
K\end{array}$ & 82.1 & $\begin{array}{l}A D L \\
12.3 \\
-0.4087\end{array}$ & & & & & $\begin{array}{l}0.66 \\
2.13\end{array}$ \\
\hline 4.2 & & $A D L$ & $C P$ & & & & \\
\hline$T$ & & 13.7 & 6.8 & & & & 0.73 \\
\hline$K$ & 75.1 & -0.4127 & 0.09538 & & & & 1.92 \\
\hline 4.3 & & $A U F$ & $C P$ & $A D L$ & & & \\
\hline$T$ & & 4.7 & 7.3 & 4.7 & & & 0.77 \\
\hline K & 48.3 & 0.3113 & 0.09850 & -0.2297 & & & 1.83 \\
\hline 4.4 & & $A \cup F$ & $C P$ & $A D L$ & $\mathrm{ASH}$ & & \\
\hline$T$ & & 5.8 & 6.8 & 5.0 & 4.7 & & 0.79 \\
\hline$K$ & 40.7 & 0.3774 & 0.08818 & -0.2314 & 0.07772 & & 1.74 \\
\hline 4.5 & & $A U F$ & $C P$ & $C F$ & $A D F$ & $A D L$ & \\
\hline$T$ & & 3.2 & 7.2 & 4.7 & 4.3 & 6.1 & 0.79 \\
\hline K & 55.4 & 0.2410 & 0.09333 & -0.09128 & 0.08458 & -0.31548 & 1.74 \\
\hline
\end{tabular}

VI.5. Chemical criteria without Van Soest's fractions and LGS

\begin{tabular}{|c|c|c|c|c|c|c|}
\hline $\begin{array}{l}5.1 \\
T \\
K\end{array}$ & 23.9 & $\begin{array}{l}\text { LGS } \\
12.0 \\
0.6120\end{array}$ & & & & $\begin{array}{l}0.65 \\
2.15\end{array}$ \\
\hline $\begin{array}{l}5.2 \\
T \\
K\end{array}$ & 14.6 & $\begin{array}{l}\text { LGS } \\
13.9 \\
0.6322\end{array}$ & $\begin{array}{l}C P \\
7.4 \\
0.1034\end{array}$ & & & $\begin{array}{l}0.74 \\
1.91\end{array}$ \\
\hline $\begin{array}{l}5.3 \\
T \\
K\end{array}$ & 35.2 & $\begin{array}{l}\text { LGS } \\
8.0 \\
0.4659\end{array}$ & $\begin{array}{l}C P \\
6.9 \\
0.09359\end{array}$ & $\begin{array}{l}C F \\
4.3 \\
-0.03231\end{array}$ & & $\begin{array}{l}0.77 \\
1.83\end{array}$ \\
\hline $\begin{array}{l}5.4 \\
T \\
K\end{array}$ & 28.5 & $\begin{array}{l}\text { LGS } \\
9.1 \\
0.5212\end{array}$ & $\begin{array}{l}C P \\
6.3 \\
0.08344\end{array}$ & $\begin{array}{l}C F \\
4.7 \\
-0.3455\end{array}$ & $\begin{array}{l}A S H \\
4.4 \\
0.07365\end{array}$ & $\begin{array}{l}0.79 \\
1.75\end{array}$ \\
\hline
\end{tabular}


Table VI. Continued

\begin{tabular}{lllllllll}
\hline Equation & 0 & 1 & 2 & 3 & 4 & 5 & $\begin{array}{l}\text { Rc } \\
\text { RSD }\end{array}$ \\
\hline
\end{tabular}

VI.6. Chemical criteria without Van Soest's fractions

\begin{tabular}{|c|c|c|c|c|c|c|}
\hline $\begin{array}{l}6.1 \\
T\end{array}$ & & $\begin{array}{l}A \cup F \\
12.0\end{array}$ & & & & 0.65 \\
\hline$K$ & 32.9 & 0.5527 & & & & 2.15 \\
\hline 6.2 & & $A U F$ & $C P$ & & & \\
\hline$T$ & & 13.7 & 7.1 & & & 0.73 \\
\hline$K$ & 24.4 & 0.5660 & 0.10032 & & & 1.92 \\
\hline 6.3 & & $A U F$ & $C P$ & $A S H$ & & \\
\hline$T$ & & 14.9 & 6.6 & 4.4 & & 0.76 \\
\hline$K$ & 16.7 & 0.6335 & 0.09010 & 0.07704 & & 1.84 \\
\hline $6.3 a$ & & $A \cup F$ & $C P$ & $C F$ & & \\
\hline$T$ & & 6.6 & 6.6 & 2.4 & & 0.74 \\
\hline$k$ & 38.6 & 0.4407 & 0.09366 & 0.02284 & & 1.89 \\
\hline 6.4 & & $A U F$ & $C P$ & $A S H$ & $S T A$ & \\
\hline$T$ & & 13.0 & 6.7 & 4.9 & 2.6 & 0.77 \\
\hline$\kappa$ & 18.3 & 0.5885 & 0.09029 & 0.08729 & 0.00465 & 1.81 \\
\hline
\end{tabular}

VI.7. Chemical and morphological criteria (1 to 13)

\begin{tabular}{|c|c|c|c|c|c|c|c|}
\hline 7.1 & & $A D L$ & & & & & \\
\hline$T$ & & 12.3 & & & & & 0.66 \\
\hline$\kappa$ & 82.1 & -0.40874 & & & & & 2.13 \\
\hline 7.2 & & $A D L$ & $C P$ & & & & \\
\hline$T$ & & 13.7 & 6.8 & & & & 0.73 \\
\hline$K$ & 75.1 & -0.4127 & 0.09538 & & & & 1.92 \\
\hline 7.3 & & $A D L$ & $C P$ & $C F$ & & & \\
\hline$T$ & & 7.6 & 6.4 & 4.1 & & & 0.76 \\
\hline$K$ & 79.6 & -0.3019 & 0.08776 & -0.03194 & & & 1.85 \\
\hline 7.4 & & $A D L$ & $C P$ & $A G E$ & $D M$ & & \\
\hline$T$ & & 13.1 & 7.4 & 6.7 & 5.8 & & 0.80 \\
\hline K & 74.7 & -0.3957 & 0.09632 & 0.08792 & -0.01476 & & 1.71 \\
\hline 7.5 & & $A D L$ & $C P$ & $A G E$ & $D M$ & $N D F$ & \\
\hline$T$ & & 10.1 & 7.3 & 6.6 & 6.6 & 3.3 & 0.81 \\
\hline$K$ & 81.52 & 0.3405 & 0.09259 & 0.08427 & -0.01662 & -0.01511 & 1.67 \\
\hline
\end{tabular}


Table VI. Continued

\begin{tabular}{lllllllll}
\hline Equation & 0 & 1 & 2 & 3 & 4 & 5 & Rc \\
& & & & & & & & RSD \\
\hline
\end{tabular}

VI.8. Chemical criteria (6 to 13)

8.1

$T$

K

8.2
$T$
$K$

8.3

K

$8.3 \mathrm{a}$ *

K

8.4

K

8.5

K $\begin{array}{ll} & A D L \\ & 12.3 \\ 82.1 & -0.40874\end{array}$

$A D L \quad C P$

$13.7 \quad 6.8$

$\begin{array}{lll}75.1 & -0.4127 & 0.09538\end{array}$

0.66

2.13

0.73

1.92

0.76

1.85

79.6

$A D L$

7.6
-0.3019

6.4

0.08776

CF

4.1

$-0.03194$

$\mathrm{ADF}$

ADL

7.2
-0.3301

$C P$

6.5

0.0908

2.2

0.74

77.7

$A D L$

8.9

78.3

$-0.4015$

$C P$

6.6

0.08728

CF

5.4

$-0.1047$

4.1

0.78

1.78

$A D L$

77.8

CP

6.1

CF

4.4

$A D F$

2.9

ASH

8.8
-0.3942

0.08069

$-0.08898$

0.06253

2.5

0.79

1.75

V1.9. Chemical criteria without Van Soest's fractions $(6,7,8,12$ and 13)

9.1
$T$
$K$

9.2
$T$
$K$

9.2

9.3

K

9.4

K $\begin{array}{ll} & C F \\ & 11.0 \\ 87.9 & -0.07549\end{array}$

CF $\quad C P$

$11.2 \quad 5.0$

$-0.07270 \quad 0.07656$

78.5

CF

9.8

92.1

$-0.10584$

$C P$

4.2

0.06393

$C P$

$8.5 \quad 3.5$

102.7

CF

$-0.12660 \quad 0.05560$
0.62

2.22

0.67

2.10

0.70

2.03

0.71

2.01

$T: T$-test on regression coefficients; $K$ : regression coefficient; $R C$. correlation coefficient; $R S D$ : residual standard deviation; * without $C F$. 
model is LGS-CP (1.2). LGS solubility can be replaced by $A U F$ solubility using models 2.4 and $2.2 \mathrm{a}$.

The best combination of morphological criteria gives a model whose correlation only reaches 0.39 (DM, EAR and $A G E$ ). No result is given for those criteria because of its weak accuracy.

We observe that the $O M D$ prediction gives rather poor correlation from the chemical composition. This point has been discussed by Andrieu et al (1993).

\section{NEAR INFRARED SPECTROSCOPY}

All the chemical parameters and enzymatic solubilities (6 to 15 in table I) can be calibrated by near infrared (NIR) spectroscopy. Several publications (Norris et al, 1976; Shenk et al, 1981; Murray, 1983; Biston and Dardenne, 1985; Coleman and Windham, 1989; Barber et al, 1990) underline the possibility to predict in vivo digestibility from NIR spectra.
All the samples (234) were dried overnight in an oven at $40^{\circ} \mathrm{C}$ to stabilize their residual water content and then measured on a monochromator (Pacific Scientific 6250) between 1100 and $2500 \mathrm{~nm}$ by $2-$ $\mathrm{nm}$ steps. The calibration procedure is the partial least square regression (PLS) (Martens and Jensen, 1982). The number of terms (factors) to introduce in the model is determined by cross-validation. This procedure (Shenk, 1991) consists of selecting two-thirds of the samples on which a model is developed. This is applied to the remaining samples. The procedure is repeated 3 times while always keeping samples for validation. The errors arising from the 3 models are added up to obtain a SD of validation whose minimum gives the number of factors to use in the model to avoid overfitting. The final model is recalculated on all the samples.

Table VII shows the results of the NIR calibrations for chemical criteria, enzymatic solubilities, in vivo $O M D$ and even energetic value ("unité fourragère") (Jarrige, 1988). The prediction of solubility gives results

Table VII. Results of NIR prediction of chemical criteria, solubilities, in vivo OMD and feeding units.

\begin{tabular}{|c|c|c|c|c|c|c|c|}
\hline Constituents & $N$ & $M$ & Min & Max & $\mathrm{Sd}$ & Sev & $\mathrm{Rp}$ \\
\hline $6 A S H$ & 237 & 48 & 32 & 80 & 7.7 & 3.8 & 0.88 \\
\hline $7 C P$ & 237 & 74 & 50 & 99 & 9.3 & 2.6 & 0.96 \\
\hline $8 \mathrm{CF}$ & 237 & 208 & 157 & 280 & 22.9 & 9.2 & 0.92 \\
\hline $9 \mathrm{NDF}$ & 237 & 473 & 389 & 575 & 34.3 & 18.7 & 0.84 \\
\hline $10 A D F$ & 237 & 229 & 17.4 & 302 & 25.1 & 10.4 & 0.91 \\
\hline $11 A D L$ & 237 & 24 & 11 & 37 & 4.6 & 2.6 & 0.83 \\
\hline $12 S T A$ & 237 & 236 & 29 & 404 & 81.9 & 18.4 & 0.97 \\
\hline $13 \mathrm{WSC}$ & 237 & 119 & 36 & 226 & 39.6 & 11.1 & 0.96 \\
\hline 14 AUF & 237 & 71 & 61.2 & 83.1 & 3.12 & 1.37 & 0.81 \\
\hline 15 LGS & 237 & 78.7 & 70.3 & 88.7 & 2.87 & 0.93 & 0.94 \\
\hline $17 O M D$ & 199 & 71.9 & 66.3 & 80.6 & 2.82 & 1.65 & 0.81 \\
\hline $18 U F L$ & 199 & 90.5 & 79.0 & 104.3 & 4.86 & 2.62 & 0.84 \\
\hline 19 UFV & 199 & 80.6 & 69.0 & 96.7 & 5.46 & 3.03 & 0.83 \\
\hline
\end{tabular}

$N$ : number of samples; $M$ : mean of the chemical laboratory values; Min: minimum; Max. maximum; Sot standard deviation; Sev : standard error of validation; Rp: correlation coefficient of validation. 
similar to those reached for crude fibre and $A D F$ and which are clearly superior to those of $A D L$. The highest correlation coefficient is obtained for starch (0.97). The results concern equations on a monochromator when using all the spectral information between 1100 and $2500 \mathrm{~nm}$. Similar equations can be obtained on filter instruments with a slight loss of accuracy.

If in all previously-developed in vivo prediction equations (table VI), we replace chemical and reference enzymatic values by its estimated values from spectral models, we notice that the results are very similar (table VIII). Replacing reference values in $O M D$ prediction models by estimated values by NIRS does not alter the accuracy of the in vivo OMD. Table VIII shows the comparison for 5 models $(1.2,5.3$, $6.3 a, 1.5$ and 3.5 in table VI) in which reference values have been replaced by values arising from the spectral models. The equation $5.3^{\prime}$ and $6.3 a$ were published in 1991 in an information paper.

NIRS is able to predict $O M D$ in a direct manner and is also even able to predict the energetic values (UFL or UFV). OMD is predicted with a validation error of 1.65 . Only the models $1.4,1.5$ and 2.5 of table VI succeed in predicting with a better accuracy but including climatic parameters which can obviously not be observed in the spectrum. Either by MLR (multiple linear regression) or by PLS (partial least squares), we observe that the main $a b-$ sorption bands explaining OMD are 1668 and $2270 \mathrm{~nm}$, corresponding to lignin absorptions. Other bands are considered and related to other constituents; 2050 and $2190 \mathrm{~nm}$ (protein), $2100 \mathrm{~nm}$ (starch), 1224 and $2332 \mathrm{~nm}$ (cellulose). Other wavelengths are relevant but without unknown specific absorptions and are used to minimize the interferences.

Table VIII. OMD prediction from chemical and enzymatic values determined by NIR.

\begin{tabular}{|c|c|c|c|c|c|c|c|}
\hline Equations & 0 & 1 & 2 & 3 & 4 & 5 & $\begin{array}{l}\text { Rc } \\
\text { RSD }\end{array}$ \\
\hline $1.2^{\prime}$ & & LGSIR & $C P \mid \mathrm{R}$ & & & & \\
\hline$T$ & & 12.8 & 6.4 & & & & 0.71 \\
\hline$K$ & 15.3 & 0.6294 & 0.09625 & & & & 2.00 \\
\hline $5.3^{\prime}$ & & LGSIR & $C P \mid \mathrm{R}$ & $C F \mathrm{IR}$ & & & \\
\hline$T$ & & 6.8 & 5.8 & 4.1 & & & 0.73 \\
\hline$K$ & 38.2 & 0.4442 & 0.08485 & -0.03572 & & & 1.92 \\
\hline $6.3 a^{\prime}$ & & $A \cup F I R$ & $C P I R$ & $C F I R$ & & & \\
\hline$T$ & & 7.5 & 6.3 & 3.4 & & & 0.74 \\
\hline$K$ & 40.7 & 0.4361 & 0.0905 & -0.0299 & & & 1.88 \\
\hline $1.5^{\prime}$ & & LGSIR & $C P$ IR & $A G E$ & $D M$ & $A D L \mathrm{IR}$ & \\
\hline$T$ & & 4.4 & 7.4 & 7.0 & 6.3 & 2.9 & 0.80 \\
\hline$K$ & 39.8 & 0.3809 & 0.09775 & 0.0937 & -0.01594 & -0.19559 & 1.70 \\
\hline $3.5^{\prime}$ & & LGSIR & $C P I R$ & $C F \mathrm{IR}$ & ASHIR & $A D L \mathbb{I R}$ & \\
\hline$T$ & & 5.2 & 5.9 & 2.2 & 4.5 & 3.7 & 0.76 \\
\hline$K$ & 46.3 & 0.3379 & 0.07516 & -0.02891 & 0.08336 & -0.18008 & 1.81 \\
\hline
\end{tabular}


If we delete these climatic and morphological parameters, the predictions by infrared models enable us to estimate $O M D$ in a more precise manner than those from models including chemical and enzymatic parameters. Feed units for milk and meat are also predicted with good correlations (correlation coefficient of prediction, $R p=$ 0.84 and 0.83 ). We have to recall that these values are the results of predictions on independent samples by crossvalidation. Besides considering the digestibility coefficient which is the most important factor, a UFL or UFV calibration, includes the other parameters which are present when computing gross energy and the coefficient of transformation of gross energy into metabolizable energy (itself function of crude fibre and total nitrogen matter content and of feeding level).

Andrieu et al (1993) showed that OMD is in reverse ratio to indigestible cell wall quantity (UNDF). On the basis of the 99 samples used by these authors, it is also feasable to predict NDF digestibility by NIRS $(R P=0.87, \operatorname{Sev}=2.6)$ and thus indigestible NDF quantity. However, as the UNDF values are based on in vivo measurements, they follow the variability observed on the in vivo OMD coefficient linked to "sheep" or site effects. Trials are now in progress to estimate NDF digestibility by enzymatic solubility.

The problem with these calibrations by NIRS is their maintenance. The calibration samples do not necessarily represent all whole plant maizes which can be found in practice. Besides the intrinsic variability due to all varieties, cutting date and phytotechnical climatic conditions, we also have to deal with the variability of the sample preparation. The latter influences the enzymatic solubility as well. This variability may be important and depends on maize quality when cropping and drying, $D M$ quantity, drying $T$, residual water content after drying, the grinding characteristics, the filling method of the cups for spectral reading and the working conditions of the spectrometer.

As for all predictions models, infrared models can only be applied within the limits defined by calibration samples. These limits can be checked in routing analysis by spectral distance measurements. The spectra of the samples to be predicted must be located within the space defined by the calibration samples. This condition is difficult to achieve and requires a huge effort in sample measurement, selection and numerous determinations by reference methods.

Since 1984, in collaboration with Limagrain, the "Station de Haute Belgique" has been collecting whole plant maize samples to develop the ENSITEC method. In 1990 , the database included 359 samples that came from a selection out of several thousands of spectra extended over several years (1985-1990). The model built on these data enables us to predict the LGS solubility of the "Club" samples with a very high accuracy $($ Sep $=1.05)$ (table IX). All the "Club" samples present spectra that are already included in the ENSITEC data base. The mean distance of the "Club" samples from the centre of gravity of the ENSITEC base is equal to 0.67 . Nevertheless, the model built only with the "Club" samples does not enable us to predict all the samples of the ENSITEC base. The accuracy gets lower ( $\operatorname{Sep}=2.34$ ) because 173 samples out of 359 have a distance $>3$ regarding the centre of gravity of the "Club" base. The ENSITEC base is wider, contains more spectral variability than the "Club" base and so is more effective in predicting the enzymatic solubility of whole plant maize. Figure 4 shows that the optical density of the ENSITEC samples present a variation that is twice as large as that of the optical densities of the "Club" samples. 
Table IX. Cross-predictions of LGS solubility between "ENSITEC" samples and Club samples.

"Club" samples predicted by “ENSITEC" equation

$\begin{array}{llll}N & \text { Sep } & R p & \text { Hbar } \\ 234 & 1.05 & 0.93 & 0.67\end{array}$

"ENSITEC" samples predicted by "Club" equation

$\begin{array}{llll}N & \text { Sep } & R p & \text { Hbar } \\ 359 & 2.34 & 0.85 & 4.34\end{array}$

$N$ : number of samples; Sep: standard error of prediction; Rp: correlation coefficient of prediction; Hbar. mean distance.

That is also true for the other chemical criteria. The weaker the constituent sensivity in the NIR region is, the more numerous the samples numbers that are required. For instance, with the same number of samples, it is well known that a protein model is more robust than a crude fibre model (lower coefficients for protein than those for crude fibre). Although it is rela-

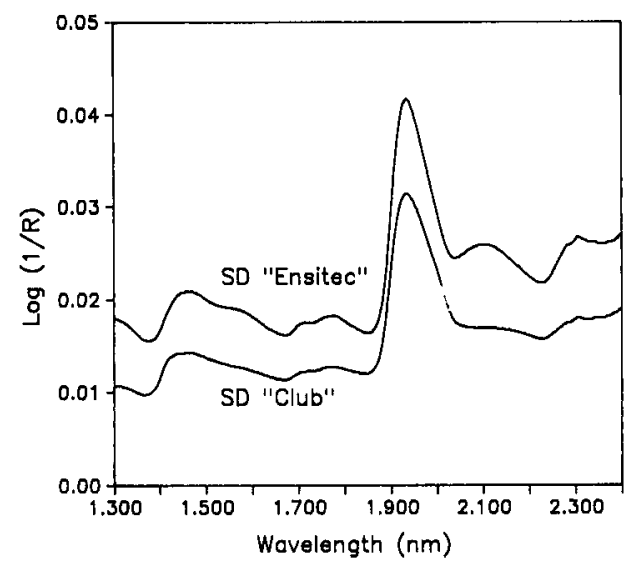

Fig 4. SD spectra for "ENSITEC" base (top) and for "Club" base (bottom). tively easy to carry out a few dozen of laboratory analyses each year to check and maintain infrared models, it is almost impossible to perform in vivo measurements on animals simultaneously. This is the reason why we advise predicting an enzymatic solubility and chemical criteria with the highest accuracy and to apply a model that links these criteria to in vivo digestibility.

\section{CONCLUSION}

The data base set up in collaboration with INRA, AGPM, ITCF and CRAGx allowed construction of linear prediction models of in vivo organic matter digestibility (OMD).

The best models explain $<70 \%$ of the observed variability in the trials on animals. This lack of fit for the individual values is compensated by a high number of points (199) which enable us to compute equations that are reliable enough to be used in practice.

NIRS seems to be an effective prediction method to determine chemical and enzymatic criteria and also to directly esti- 
mate the in vivo digestibility coefficient and feeding units.

NIRS accuracy depends on the reference value quality and models can only be applied for a given population. So it is absolutely necessary to be able to check and maintain predictive models each year by an adequate selection of new samples on which reference methods are performed.

Research on maize digestibility predictions is currently in progress at several laboratories in Europe in particular to estimate in vivo value by enzymatic methods via cell wall digestibility. Unfortunately in vivo data are no numerous enough and lack of standardization between institutions and countries does not always enable us to merge the available values to build up common databases.

\section{REFERENCES}

Andrieu J, Demarquilly $C$, Dardenne $P$, Barriere Y, Lila M, Maupetit P, Riviere F, Femenias N (1992) Composition and nutritive value of whole maize plants fed fresh to sheep. I. Factors of variation. Ann Zootech 42, 221-249

Aufrère J, Michalet-Doreau B (1983) In vivo digestibility and prediction of digestibility of some by-products. EEC Seminar, 26-29 September 1983, Melle-Gontrode, Belgique

Barber GD, Givens DI, Kridis MS, Offer NW, Murray I (1990) Prediction of the organic matter digestibility of grass silage. Anim Feed Sci Technol 28, 115-128

Barriere $Y$, Demarquilly $C$, Herbert $Y$, Dardenne $P$, Andrieu J, Maupetit $P$, Lila M, Émile JC (1991) Influences de la variabilité génétique et environnementale sur la digestibilité in vi- tro ou in vivo du maïs fourrage. agronomie 11, 151-157

Biston R, Dardenne P (1985) Application de la spectrométrie de réflexion dans le proche infrarouge. Prévision de la qualité des fourrages en vue de leur exploitation rationnelle. Bull Rech Agron Gembloux 20 (1/2), 23-41

Biston R, Dardenne P, Demarquilly C (1989) Determination of forage in vivo digestibility by NIRS. XVI Int Grassland Congress, 4-11 October, 1989, Nice, France

Dardenne P, Biston R (1990) Standardization procedure and NIR instrument network. In: Proc Third Int Near Infared Spectroscopy Conf. 25-29 juin 1990, Brussel, Belgium

Coleman SW, Windham WR (1989) In vivo and in vitro measurements of forage quality in near infrared spectroscopy in analysis of forage quality. In: USDA Agric Handbook No 643. $82-83$

Jarrige R (1988) Alimentation des Bovins, Ovins et Caprins: Collective Study. INRA, pp 472

Martens $H$, Jensen SA (1982) Partial least squares regression: a new two-stage NIR calibration method. In: Proc 7th World Cereal Bread Congr (Holas, Kratchovil, eds) Elsevier, Amsterdam, 607-647

Murray I (1989) Application of NIRS in agriculture. In: Proc 2nd int Near Infrared Spectroscopy Conference, 29 May-2 June 1989, Tsukuba, Japon

Norris KH, Barnes RF, Moore JE, Shenk JS (1976) Predicting forage quality by infrared reflectance spectroscopy. J Anim Sci 43, 889/897

Shenk JS, Landa I, Hoover MR, Westerhaus MO (1981) Description and evaluation of a near infrared reflectance spectro-computer for forage and grain analysis. Crop Sci 21, 355-358

Shenk JS (1991) ISI User's Manual

Shenk JS, Westerhaus MO (1991) Population definition, sample relation and calibration procedures for Near Infrared Reflectance Spectroscopy. Crop Science 31, 469-474 